\title{
Current COVID-19 Pandemic and Medical Education: Medical Students' Perception and Experiences with Online Clinical Teaching and Learning at College of Medicine in Oman
}

\author{
Firdous Jahan, Muhammad Siddiqui, Muzna S. R. Al-Asmi, and Manar R. S. Al-Shahi
}

\section{ABSTRACT}

Background: Clinical teaching is a form of interpersonal communication between a teacher and learner. It mainly involves a patient or a patient scenario; the student learns how to evaluate a patient and manage the problem. The ideal clinical teaching and learning are done in the patient care area, but because of the COVID19 pandemic outbreak, all clinical and classroom teaching is suspended now.

Objective: This study's main purpose was to assess medical students' perceptions and experiences with online clinical teaching and learning. Method: A cross-sectional study was conducted at the College of Medicine and Health Sciences (CoMHS). All students in 6 and 7 years consented to participate in the survey for a self-filled study (google form). Statistical analysis was performed using Statistical Package for Social Sciences (IBM SPSS Statistics 24.0). Data were expressed in frequencies for questionnaire responses calculated for all variables in numbers and percentages. Independent sample t-test was used to compare differences between two groups.

Result: Ninety-one students participated in the study, of which $10.2 \%$ were male, and $46.2 \%$ were Omani citizens. $27.5 \%$ of students were 6th year, and $72.5 \%$ were 7 th-year students. $69.2 \%$ of students did not experience any login/registration problem in GoToWebinar most of the time. Table 1 shows the student's responses in this regard. A significant statistical difference (p- $<0.001 ; 95 \%$ CI: 0.34-0.91) was observed between 6th year (mean-2.79 \pm 0.62$)$ and 7 th year students (mean$2.16 \pm 0.51)$.

Conclusion: Medical students have shown a positive attitude and motivation towards webinar clinical teaching. Online webinar teaching can offer more diverse and compelling educational opportunities. Medical students in clinical years are self-directed learners but need indepth learning with maximum hands-on practice. The Webinar teaches an impact on medical student education, particularly affecting the hands-on approach and training, which is limited and mandatory to become a doctor.

Keywords: COVID-19 pandemic, clinical teaching, assessment, medical students

\section{INTRODUCTION}

Engaging students in webinar clinical teaching sessions is a challenging job. This learning model encourages students to control their education and allow them flexibility over content and learning pace [1]. The constructive social theory has components of teaching presence, social and cognitive presence leading to students' engagement for in-depth understanding in the clinical context, developing clinical reasoning skills, and self-directed learning with selfmotivation. Clinical assessment requires tasks that assess cognitive, psychomotor, and communication skills evaluate
Published Online: April 30, 2021

ISSN: $2736-5476$

DOI: 10.24018 / ejclinicmed.2021.2.2.23

Firdous Jahan *

College of Medicine and Health Sciences

National University, Oman

(e-mail: firdousjahan@nu.edu.om )

Muhammad Siddiqui

Saskatchewan Health Authority, Regina, SK, Canada

Muzna S.R. Al-Asmi

Medical student, College of Medicine and Health Sciences National University, Oman Manar R. S. Al-Shahi

Medical student, College of Medicine and Health Sciences National University, Oman

*Corresponding Author professionalism attributes. Clinical teaching involves a patient or a patient scenario; the student learns how to evaluate a patient and manage it [2-3]. The ideal clinical teaching and learning are done in the patient care area but because of the COVID-19 pandemic outbreak, all clinical and class room teaching is suspended. Online teaching is an acceptable mode of teaching; it can offer more diverse and influential educational opportunities. There is a severe and disruptive change to medical education worldwide in this pandemic. Use of technology has been rapidly used to maintain teaching and learning [4]. In response to COVID19, medical education faculty has quickly transitioned to online formats that include the COVID-19 crisis. Faculty 
facilitators learn from the experience and training and prioritize a forward thinking in medical education to advance online teaching and learning [5].

While pandemics have brought significant disruption and challenge, we have organized webinar teaching opportunities for our students. The current COVID-19 pandemic is affecting healthcare institutions in ways that may disrupt future healthcare professionals' training. Clinical teaching is a skill that must be practiced. Education is more effective when learners identify educational needs and are ready/motivated, and take responsibility for their learning. The teaching methods used in clinics and wards offer more diverse and compelling educational opportunities [6-7]. A practical and conducive learning environment facilitates indepth learning where students express their opinions, question, evaluate their own and peer performance with maximum hands-on practice. Students' focused teaching with meaning full interaction improves self-confidence and selfcontrol in learners and better in-depth learning [8].

The current COVID-19 pandemic is affecting healthcare institutions in ways that may disrupt future healthcare professionals' training. This collection features peer-reviewed teaching resources that can be used for distance learning, including self-directed modules and learning activities that could be converted to virtual interactions [9-10]. Engaging students in webinar clinical teaching sessions is a challenging job. This learning model encourages students to control their learning and allows them flexibility over content and education pace. This study's main purpose was to assess medical students' perceptions and experiences with online clinical teaching and learning.

\section{METHODS}

A cross-sectional study was conducted at the College of Medicine and Health Sciences (CoMHS). All 6th and 7thyear students consented to participate in the survey for a selffilled questionnaire (google form).

All 6th and 7th-year students were invited to participate in the study. Participants were enrolled after taking written informed consent. Data collection was carried out using a structured self-administered questionnaire, which was specially designed for this study. An online structured questionnaire was composed incorporating students' perception and experiences with online clinical teaching and learning during the current COVID-19 pandemic that were identified through an extensive literature search of the PubMed database. After the consensus of all study investigators, few questions were included, particularly important to local scenarios. Institutional Ethical Review Committee approved the study and questionnaire.

Statistical analysis was performed using Statistical Package for Social Sciences (IBM SPSS Statistics 24.0). Data were expressed in frequencies for questionnaire responses calculated for all variables in numbers and percentages. An independent sample t-test was used to compare differences between 6 th and 7 th-year student's responses.

\section{RESULTS}

A total of ninety-one students participated in the study, of which $10.2 \%$ were male, and $46.2 \%$ were Omani citizens.
$27.5 \%$ of students were 6th year, and $72.5 \%$ were 7 th-year students. Students were asked multiple questions regarding the engagement of students as partners in learning design.

Their answers were labeled as strongly agree, agree, neutral, disagree, and strongly disagree. $69.2 \%$ of students did not experience any login/registration problem in GoToWebinar most of the time. Table 1 shows the student's responses in this regard. A significant statistical difference (p$<0.001$; $95 \%$ CI: 0.34-0.91) was observed between 6th year (mean-2.79 \pm 0.62 ) and 7 th year students (mean-2.16 \pm 0.51 ).

\section{DISCUSSION}

Use The resource collection built in response to the COVID-19 pandemic's significant impact on the teaching and learning. Identifying improvements in traditional approaches and supporting innovation in curriculum planning, teaching, learning, assessment, and education management moves forward towards more distant learning [11-12]. The current COVID-19 pandemic is affecting healthcare institutions in ways that may disrupt future healthcare professionals [1314]. This collection features peer-reviewed teaching resources that can be used for distance learning, including self-directed modules and learning activities that could be converted to virtual interactions.

The patient encounter gives medical students a better opportunity to acquire appropriate medical knowledge with a diversity of cases and management approaches. There is a serious and disruptive change to medical education worldwide in this pandemic. Technology has been rapidly and innovatively used to maintain teaching and learning [1516]. In our study, $69.2 \%$ of students did not experience any login/registration problem in GoToWebinar most of the time (Table 1). A significant statistical difference (p- $<0.001 ; 95$ $\%$ CI: 0.34-0.91) was observed between 6th year (mean$2.79 \pm 0.62$ ) and 7 th year students (mean-2.16 \pm 0.51 ).

Students were generally satisfied with the teaching and learning strategies in our study. Wilcha has reported that in the times of the COVID-19 pandemic, teaching is crucial to enable the graduation of future physicians into society. The evidence suggests that virtual education is useful, and institutions are developing these resources further to improve student engagement [17-18].

Seventy four percent of students in our study think that online learning should be included in clinical teaching. The majority of the clinical students agreed that case-based Scenarios were handy, relevant, and a good practice opportunity for reflection/participation and to share knowledge opportunity of clinical learning. Alsharani et al reported in their study that educator's improved digital literacy and diverse and enriching experience extremely helpful for effective webinar teaching [19-20].

In this study, clinical students were satisfied with their reflection and participation in intradepartmental lecture /seminar and sharing experiential knowledge on Webinar. A webinar has increased the opportunity for clinical learning and flexible time for reflection. In addition, the same results are reported in published articles. Sani, The combination of recent telecommunication developments with current teaching methodologies may positively change medical education's future landscape [21-23]. 
Regarding the feedback and assessment during online teaching, students feel that facilitators have given constructive feedback to motivate in-depth learning and critical thinking and reasoning in clinical education and learning (Fig I). Clinical year teaching is mainly self-directed learning; however, teachers' guidance and feedback stimulate motivation and critical thinking process [24-26]. Disruption during pandemic has an enormous effect on students' confidence and preparedness to become a practicing doctor. As a front-line workforce, it is crucial to maintain their wellbeing with safeguards such as proper inductions, support, and supervision [27-29].

\section{CONCLUSION}

Medical students in clinical years have shown a positive attitude and motivation towards webinar clinical teaching. Online teaching is an acceptable mode of education; it can offer more diverse and adequate educational opportunities. Medical students in clinical years are supposed to be independent, self-directed learners to motivate and facilitate in-depth learning with maximum hands-on practice. The Webinar teaches an impact on medical student education and particularly affecting the transition from student to doctor.

TABLE 1: STUDENTS ENGAGEMENT AS PARTNERS IN LEARNING DESIGN

\begin{tabular}{|c|c|c|c|c|c|}
\hline & $\begin{array}{l}\text { Strongly } \\
\text { Agree }\end{array}$ & Agree & Neutral & $\begin{array}{l}\text { Disa } \\
\text { gree }\end{array}$ & $\begin{array}{l}\text { Strongly } \\
\text { disagree }\end{array}$ \\
\hline $\begin{array}{l}\text { I have } \\
\text { adequate } \\
\text { time for } \\
\text { case based } \\
\text { preparation } \\
\text { and } \\
\text { discussion }\end{array}$ & $11(12.1)$ & $\begin{array}{l}50 \\
(54.9)\end{array}$ & $22(24.2)$ & $6(6.6)$ & $2(2.2)$ \\
\hline $\begin{array}{l}\text { This was a } \\
\text { good } \\
\text { opportunity } \\
\text { for } \\
\text { reflection/p } \\
\text { articipation } \\
\text { and to share } \\
\text { knowledge }\end{array}$ & $15(16.5)$ & $\begin{array}{l}47 \\
(51.6)\end{array}$ & $23(25.3)$ & $3(3.3)$ & $3(3.3)$ \\
\hline $\begin{array}{l}\text { Case based } \\
\text { Scenarios } \\
\text { were very } \\
\text { useful, } \\
\text { relevant } \\
\text { and } \\
\text { practical }\end{array}$ & $20(22)$ & $\begin{array}{l}46 \\
(50.5)\end{array}$ & $15(16.5)$ & $7(7.7)$ & $3(3.3)$ \\
\hline $\begin{array}{l}\text { I have } \\
\text { learnt how } \\
\text { to become a } \\
\text { facilitator } \\
\text { and peer } \\
\text { teacher }\end{array}$ & $9(9.9)$ & $\begin{array}{l}32 \\
(35.2)\end{array}$ & $35(38.5)$ & $\begin{array}{l}14 \\
(15.4)\end{array}$ & $1(1.1)$ \\
\hline $\begin{array}{l}\text { I have } \\
\text { adequate } \\
\text { time for } \\
\text { case based } \\
\text { preparation } \\
\text { and } \\
\text { discussion } \\
\text { (n-59) }\end{array}$ & $6(10.2)$ & $\begin{array}{l}33 \\
(55.9)\end{array}$ & $12(20.3)$ & 8 (13.6) & 0 \\
\hline $\begin{array}{l}\text { I had given } \\
\text { the } \\
\text { opportunity } \\
\text { to talk and } \\
\text { discuss }\end{array}$ & $25(27.5)$ & $\begin{array}{l}48 \\
(52.7)\end{array}$ & $12(13.2)$ & $5(5.5)$ & $1(1.1)$ \\
\hline $\begin{array}{l}\text { Facilitation } \\
\text { of the } \\
\text { clinical }\end{array}$ & $17(18.7)$ & $51(56)$ & $19(20.9)$ & $3(3.3)$ & $1(1.1)$ \\
\hline
\end{tabular}

\begin{tabular}{|c|c|c|c|c|c|}
\hline $\begin{array}{l}\text { session by } \\
\text { faculty was } \\
\text { very } \\
\text { smooth } \\
\text { good and } \\
\text { informative }\end{array}$ & & & & & \\
\hline $\begin{array}{l}\text { My } \\
\text { reflection } \\
\text { and } \\
\text { participatio } \\
\mathrm{n} \text { in IDL } \\
\text { was } \\
\text { satisfactory } \\
\text { with } \\
\text { sharing } \\
\text { experiential } \\
\text { knowledge } \\
\text { on webinar }\end{array}$ & $14(15.4)$ & $40(44)$ & $30(33)$ & $6(6.6)$ & $1(1.1)$ \\
\hline $\begin{array}{l}\text { Webinar } \\
\text { has } \\
\text { increased } \\
\text { my } \\
\text { opportunity } \\
\text { of clinical } \\
\text { learning }\end{array}$ & $11(12.1)$ & $\begin{array}{l}12 \\
(13.2)\end{array}$ & $24(26.4)$ & $\begin{array}{l}36 \\
(39.6)\end{array}$ & $8(8.8)$ \\
\hline $\begin{array}{l}\text { Learning } \\
\text { resource } \\
\text { material } \\
\text { was easy to } \\
\text { access, } \\
\text { useful and } \\
\text { relevant (n- } \\
\text { 59) }\end{array}$ & $5(5.5)$ & $\begin{array}{l}37 \\
(62.7)\end{array}$ & $12(20.3)$ & $4(6.8)$ & $1(1.7)$ \\
\hline $\begin{array}{l}\text { I am } \\
\text { satisfied / } \\
\text { proud of } \\
\text { the way my } \\
\text { institution } \\
\text { responded } \\
\text { to social } \\
\text { and health } \\
\text { demands in } \\
\text { the face of } \\
\text { the } \\
\text { pandemic } \\
\text { (n-59) }\end{array}$ & $30(50.8)$ & $\begin{array}{l}20 \\
(33.9)\end{array}$ & $9(15.3)$ & 0 & 0 \\
\hline
\end{tabular}

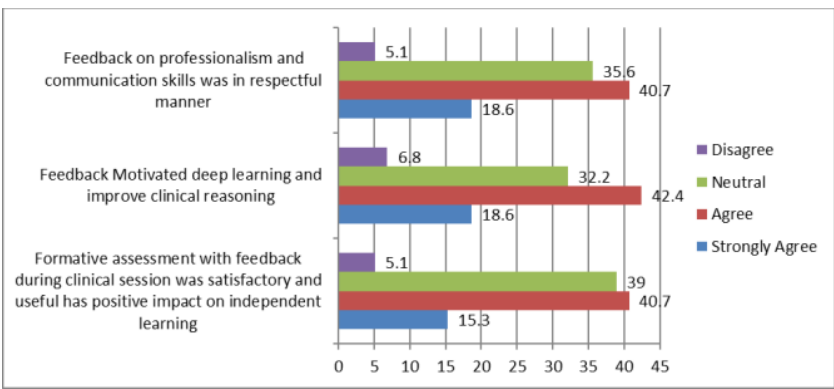

Fig. 1. Assessment during teaching session.

\section{CONCLUSION}

Medical students have shown a positive attitude and motivation towards webinar clinical teaching however, in clinical years they need maximum hands-on practice.

\section{ACKNOWLEDGMENT}

The authors would like to express gratitude to Dr Muhammad Al Shafaee, Dean College of Medicine and Health Sciences and Dr John Muthusami Assistant Dean Clinical affair for their valuable and constructive suggestions. 


\section{REFERENCES}

[1] COVID-19 updates and resources. Liaison Committee on Medical Education. Updated March 25, 2020. Accessed March 27, 2020. [Online]. Available: https:// lcme.org/covid-19/

[2] Important guidance for medical students on clinical rotations during the coronavirus (COVID-19) outbreak. Press release. Association of American Medical Colleges. Published March 17, 2020. Accessed March 23, 2020. [Online]. Available: https://www.aamc.org/newsinsights/press-releases/important-guidance-medical-students-clinicalrotations-during-coronavirus-covid-19-outbreak

[3] Skochelak SE, Stack SJ. Creating the medical schools of the future. Acad Med. 2017;92(1):16-19.

[4] Mohammed A A, Ahmad Al-K, Ahmad A. Exploring the critical challenges and factors influencing the E-learning system usage during COVID-19 pandemic. Education and Information Technologies. [Online]. Available: https://doi.org/10.1007/s10639-020-10219-y

[5] Nitin G, Suresh T. Interactive E-learning module in pharmacology: a pilot project at a rural medical college in India. Perspect Med Educ 2014; 3:15-30

[6] David A. Armstrong students' perceptions of online learning and instructional tools: a qualitative study of undergraduate students use of online tools. tojet: The Turkish Online Journal of Educational Technology July 2011;10(3)

[7] Cantillon P, Irish B, Sales D. Using computers for assessment in medicine. BMJ. 2007;329:606-609.

[8] Dennick R, Wilkinson S, Purcell N. Online e Assessment: AMEE guide no. 39. Med Teach. 2009 Mar;31(3):192-206.

[9] Walsh K. Online assessment in medical education-current trends and future directions. Malawi medical journal: the journal of Medical Association of Malawi; 27(2): 71-72.

[10] Goh P, Sandars J. 'A vision of the use of technology in medical education after the COVID-19 pandemic', Med Ed Publis; 9(1): 49.

[11] Frenk J, Chen L, Bhutta ZA, Cohen J, Crisp N, Evans T, Fineberg H, Garcia P, Ke Y, Kelley P, Kistnasamy B, Meleis A, Naylor D, PablosMendez A, Reddy S, Scrimshaw S, Sepulveda J, Serwadda D, Zurayk $H$. Health professionals for a new century: transforming education to strengthen health systems in an interdependent world. Lancet. 2010 Dec 4;376(9756):1923-58.

[12] Lall P, Rees R, Law GC, Dunleavy G, Cotic Ž, Car J. Influences on the implementation of mobile learning for medical and nursing education: qualitative systematic review by the Digital Health Education Collaboration. J Med Internet Res. 2019 Feb 28;21(2):e12895. doi: $10.2196 / 12895$

[13] Kumta SM, Tsang PL, Hung LK, Cheng JCY. Fostering critical thinking skills through a web-based tutorial program for final year medical students-A randomized controlled study. J Educ Multimed Hypermedia. 2003;12(3):267-73.

[14] Posel N, McGee JB, Fleiszer DM. Twelve tips to support the development of clinical reasoning skills using virtual patient cases. Med Teach. 2014 Dec 19;1-6.

[15] Subramanian A, Timberlake M, Mittakanti H, Lara M, Brandt ML. Novel educational approach for medical students: improved retention rates using interactive medical software compared with traditional lecture-based format. J Surg Educ. 2012;69(2):253-6.

[16] Nunohara et al. How does video case-based learning influence clinical decision-making by midwifery students? An exploratory study. BMC Medical Education, 2020; 20:67.

[17] Wilcha RJ. Effectiveness of Virtual Medical Teaching During the COVID-19 Crisis: Systematic Review. JMIR Med Educ. 2020 Nov 18;6(2):e20963.

[18] Sargeant J, Curran V, Jarvis-Selinger S, Ferrier S, Allen M, Kirby F, et al. Interactive online continuing medical education: physicians' perceptions and experiences. J Contin Educ Health Prof. 2004;24(4):227-36

[19] Shinji K, Hirotaka O, Minori K. Characteristics and perceptions of twice-weekly webinars for primary care physicians in Japan: a qualitative study. International Journal of Medical Education. 2018;9:229-238

[20] Alshahrani I. Orienting Faculty and Students with Online Teaching Webinar Experiences in Saudi Arabia. Ann Med Health Sci Res. 2019;9:443-447

[21] Cheston CC, Flickinger, Chisolm MS. Social Media Use in Medical Education: A Systematic Review. Acad Med. 2013;88(6):893-901.

[22] Sani I, Hamza Y, Chedid Y, Amalendran J, Hamza N. Understanding the consequence of COVID-19 on undergraduate medical education: Medical students' perspective. Ann Med Surg (Lond). 2020 Sep 5;58:117-119.
[23] White C, Bradley E, Martindale J, et al. Why are medical students' checking out' of active learning in a new curriculum? Med Educ. 2014;48:315-324.

[24] Hayashi S, Tsunekawa K, Inoue C, Fukuzawa Y Comparison of tutored group with tutor less group in problem-based mixed learning sessions a randomized cross-matched study. BMC Med Educ. 2013;13:158.

[25] Stein GH, Shibata A, Bautista M. Webinar: free international distant real time interactive tutoring. Med Teach. 2010;32:619-620.

[26] Suzanne Rose. Medical Student Education in the Time of COVID19.JAMA June 2, 2020;23(21): 2131-32.

[27] Sabzwari S. 'Rethinking Assessment in Medical Education in the time of COVID-19', Med Ed Publish2020; 9 (1): 80.

[28] Ahmed H., Allaf, M. and Elghazaly, H. 'COVID-19 and medical education, The Lancet Infectious Diseases, 2020 https://doi.org/10.1016/S1473-3099(20)30226-7

[29] Humphrey-Murto, S., Wood, T. J., Ross, S., Tavares, W. et al 'Assessment pearls for competency-based medical education', Journal of Graduate Medical Education 2017; 9(6): 688-691.

[30] Choi B, Jegatheeswaran L, Minocha A, Alhilani M, Nakhoul M, Mutengesa E. The impact of the COVID-19 pandemic on final year medical students in the United Kingdom: a national survey. BMC Med Educ. 2020 Jun 29;20(1):206. 